\title{
Determinants of Corporate Social Responsibility Disclosure: Empirical Evidence from Indonesia Stock Exchange
}

\author{
Dita Ayu Lestari, Noegrahini Lastiningsih, Shinta Widyastuti \\ Universitas Pembangunan Nasional Veteran Jakarta, Indonesia \\ noegrahini@gmail.com
}

\begin{abstract}
This study aims to examine the relationship between consumer proximity, environmental performance, profitability, and media exposure on corporate social responsibility disclosure. This study used data from companies listed in Indonesia Stock Exchange (IDX) 2017-2019. A purposive sampling method was used in this study with 60 samples on the Indonesia Stock Exchange. Hypothesis testing in this study using multiple linear regression with SPSS. The results show that consumer proximity has a positive effect on corporate social responsibility disclosure. Meanwhile, environmental performance, profitability, media exposure does not affect corporate social responsibility disclosure. The implication of this study is for the companies to increase social responsibility to the stakeholders and community due to the positive reciprocal relationship.
\end{abstract}

Keywords: CSR Disclosure, Consumer proximity, Environmental performance, Profitability, Media exposure.

\section{Introduction}

Companies are institutions that are considered to provide many benefits to society. Much labor is absorbed, people's consumption needs are met, pay taxes, and other contributions are obtained from the company. However, if examined from the negative side, the company in carrying out its production activities can produce waste in the form of waste, causing environmental pollution, degradation of ecosystem quality, and sustainable natural damage that can harm the community (Fitriyani and Mutmainah, 2012). This phenomenon was reported by the website industry. Kontan, id 2009 in which the Sinarmas Group was criticized by Greenpeace that the company had destroyed forests and peatlands so that this condition led to deforestation. Changes in forest land use have led to an increase in greenhouse gas emissions. One of the results of the audit showed that the Sinarmas Group was logging the forest before the AMDAL permit was issued. This condition caused several companies to terminate their cooperation with the Sinamas Group in ordering palm oil. This problem should reflect on the Law on Limited Liability Companies No. 40 of 2007 which contains the obligation for companies to provide information related to their CSR activities. Corporate Social Responsibility (CSR) disclosure in corporations aims to encourage business entities in the business world to be more ethical in carrying out their operational activities so that they do not intersect and have a negative impact on society and the environment. One of the ways corporations grow their business, maintain, and legitimize the company's contribution from the economy and politics is to increase the intensity of disclosure of the company's CSR implementation (Wardhani and Sugiharto, 2013; Yingjun et al., 2015).

It should be in accordance with the Law on Environmental Protection and Management No. 32 of 2009 that companies are required to maintain and protect the elements of life around them by minimizing adverse risks to the environment due to corporate operational activities. Corporations must pay attention to the three main pillars which are commonly known as 3P, namely Planet, People, and Profit. The company is no longer a business institution that only targets a successful financial performance by maximizing its business profit (profit-oriented), but the company is also obliged to take responsibility for the company's operating activities that have a direct impact on the environment around the organization (Yuliskayani and Damayanti, 2018). Several studies link CSR disclosure with several variables such as consumer proximity, environmental performance, profitability and media exposure which are shown with inconsistent results. Consumer Proximity is the closeness of customers in a product produced by a goods company or in the service sector. In connection with the visibility perspective, companies that produce or sell goods and services that are widely consumed by the community will tend to produce more social visibility (Wang, et al., 2013). The company considers that public exposure is vital to the company's success in maintaining a good image. Companies classified as having a consumer proximity are companies engaged in manufacturing, textiles or garments, food, household goods, telecommunications services, retail food and beverages, and the financial sector. Environmental performance is the relationship that occurs from a corporation with the surrounding 
environment regarding what are the effects on the environment for something that has been done. Environmental relations for commodities and services, restoration and complying with environmental regulation for activities (Damanik and Yadnyana, 2017).

Using PROPER which was proclaimed by the Ministry of Environment which aims to disseminate information related to environmental performance and to increase the level of company performance improvement (Lastiningsih and Aswar, 2020). If the company pays close attention to environmental performance, the company has implemented CSR as there is evidence of the company's high attention to environmental and social concerns (Halmawati and Oktalia, 2015). Profitability is one of the goals of the company that is usually achieved by organizations. The level of profitability can indicate the condition of the company's management. Therefore, if the company has large profitability, the higher the disclosure of its social responsibility (Pakpahan and Rajagukguk, 2018). Therefore, the company's profitability can be linked to the company's CSR disclosure. Profitability is proxied by using ROA where the ratio reflects the company's capability in creating profits from its investment sector.

Partalidou et al. (2020) found that CSR disclosure is an important factor for the company's financial performance, intended with the aim of increasing transparency and indicating that they operate in accordance with community norms, all of these stages are important for the company so that the interests of stakeholders can be found. Furthermore, information media is growing rapidly in today's high technology era, information media is considered to be a bridge for anyone who needs information. In the past few years, newspapers are a common form of container for companies to disclose CSR activities. Internet media (web) is an option that can be said to be effective in disclosing corporate CSR, this is in line with the increasing use of the internet among the public. The purpose of this study is to determine the effect of consumer proximity, environmental performance, profitability, and media exposure on corporate social responsibility disclosure.

\section{Literature Review and Hypothesis Development}

Legitimacy Theory: Legitimacy theory is a theory that explains how companies interact with the community. Legitimacy can be defined as whether the actions taken by the company are appropriate or appropriate within the corridor of a system of social norms, values and beliefs. Legitimacy theory states that companies continue to strive to confirm that company has worked within the norms and boundaries of society (Syed and Butt, 2017). This legitimacy theory is widely found and used in the literature to explain CSR disclosure practices. Legitimacy is considered important because for companies the community legitimacy obtained by the company can be a strategic aspect in the future regarding the concept of sustainability.

Stakeholders Theory: In the theory of stakeholders, the company is not only engaged in its interests but must also be able to share benefits for its stakeholders (Freeman and McVea, 2001). One of the benefits that a company can provide is the implementation of its CSR program. This CSR program is certainly expected to be able to add or improve the welfare of workers, customers and society. So that a good relationship can be built between the corporation and the surrounding environment.

CSR Disclosure: World Business Council for Sustainable states that the definition of CSR is a sustainable obligation by business entities to act more morally and ethically in accordance with norms and provide participation in the economic development of the local community and the wider community, including improving the welfare of workers and their families (Aulia, 2010). Among the various reporting standards mentioned, one of them is GRI G4 which provides a relevant framework matrix to support a standardized reporting approach according to international standards. Standardized reporting encourages the concept of transparency and substantial consistency that is required to make this information useful and can be used as a reference in making decisions. Klerk et al. (2015) said that UK legislation mandates companies to disclose information related to the environmental, employee, social and community issues in annual reports but does not provide guidance on specific topics that must be addressed, and this suggests that the level of disclosure is partly large still discretionary.

Consumer Proximity: If it is related to theoretical legitimacy, the company has social and environmental factors that come from the community where these conditions need to be considered. Consumer proximity is 
the meaning of consumer closeness to products or services. Then, it can be ascertained that if consumers have a factor of closeness to a product or service, then the consumer who is part of the community will legitimize the company. Companies with high closeness to consumers have greater social visibility (Branco and Rodrigues, 2008). The closer the consumers are to the product or service, the higher the demands for CSR disclosure (Yuliskayani and Damayanti, 2018). Gamerschlag et al. (2010) in Giannarakis (2014) found that companies belonging to the consumer and energy supply industry tend to disclose more CSR information to reduce stakeholder pressure.

H1: Consumer proximity has a positive effect on CSR disclosure.

Environmental Performance: Environmental performance is a company system that is willing to integrate environmental attention and awareness of company operations and interactions with stakeholders that go beyond the legal responsibility of the organization (Lastiningsih and Aswar, 2020). Environmental performance is very important for the company. Companies that disclose environmental performance are like providing good news for the community.

H2: Environmental performance has a positive effect on CSR disclosure.

Profitability: Profit is one of the main goals of the company. Profitability can be used as consideration for companies in carrying out CSR disclosures in terms of the company's financial performance. Companies with high profitability will find it easier to respond to external demands, namely the community because the company has more funds to use in carrying out its social responsibility activities and discloses CSR responsibilities compared to companies with low profitability ownership (Dewi and Yasa, 2017). Klerk et al. (2015) suggest that if the combination of financial accounting information and CSR disclosure is combined, it can explain market value better than focusing exclusively on financial accounting information alone. Haniffa and Cook (2005) in Giannarakis (2014) suggest that the positive correlation between profitability and CSR disclosure can be drawn from the fact that profitable companies have the freedom and flexibility to more broadly expose CSR practices to stakeholders, and legitimize them.

H3: Profitability has a positive effect on CSR disclosure.

Media Exposure: Media exposure is a space used by companies to seek public trust and support. According to Branco and Rodrigues (2008) in Yuliskayani and Damayanti (2018), if the media coverage of the company is greater, the company will be the object of attention and attract further public scrutiny (Yuliskayani and Damayanti, 2018).

H4: Media exposure has a positive effect on CSR disclosure.

\section{Research Method}

The population in this study is companies listed on the IDX for the period 2017-2019. The frequency of this data is yearly. Determination of the sample using the purposive sampling method. The criteria for determining the sample which are: companies listed on the IDX 2017-2019, companies that published successive annual reports during 2017-2019, companies that generate profits during 2017-2019 and the company is registered in the PROPER of the Ministry of Environment. A total of 60 samples were found. The data used is secondary data in the form of company annual reports and company sustainability reports which are accessed through the official website of the Indonesia Stock Exchange. Data analysis using multiple regression analysis model.

\section{Results}

The total number of companies listed on the Indonesia Stock Exchange in 2017-2019, the number of companies listed in that period was 20 companies. Thus, there are 60 research samples. Based on table 1 the $\mathrm{R} 2$ value is 0.148 and it can be interpreted that as much as $14.8 \%$ is influenced by the four independent variables. While the rest $(100-14.8) 85.2 \%$ is influenced by other variables that are not explained in this study. 
Table 1: R Square

\begin{tabular}{llll}
\hline Model & R & R Square & Adjusted R Square \\
\hline 1 & $.384^{\mathrm{a}}$ & 0,148 & 0,085 \\
\hline
\end{tabular}

Table 2 below shows the regression test results indicating that consumer proximity on CSR disclosure by obtaining a significance result from the T-test of 0.022 , which illustrates that it is smaller than 0.05 so that $\mathrm{H} 1$ is accepted because it succeeds in proving the initial prediction that consumer proximity has a positive effect on CSR disclosure. And it can be concluded that consumer proximity has a positive influence on CSR disclosure. It is in line with the theory of legitimacy where the company has social and environmental factors that come from the community where these conditions and things need to be considered. It can be assumed that if the company which is included in the consumer proximity category will disclose its CSR because the companies included in this category are close companies. To their consumers, where consumers have more desire to get more information related to their company, both financial information and non-financial information. Furthermore, the consumer proximity company will provide greater CSR disclosure for consumers and other stakeholders. Giannarakis (2014) suggests that companies belonging to the health care sector, the basic needs of consumers statistically have a significant effect on the level of CSR disclosure because they are directed to include more information into CSR disclosures.

Table 2: T-test Results

\section{Coefficients}

\begin{tabular}{|c|c|c|c|c|c|c|}
\hline \multirow[b]{2}{*}{ Model } & & \multicolumn{2}{|c|}{ Unstandardized Coefficient } & \multicolumn{2}{|c|}{ Standardized Coefficients } & \multirow[b]{2}{*}{ Sig. } \\
\hline & & B & Std. Error & & $\mathrm{T}$ & \\
\hline 1 & (Constraints) & 0.184 & 0.102 & & 1.81 & 0.076 \\
\hline & $\mathrm{CP}$ & 0.104 & 0.044 & 0.331 & 2.365 & 0.022 \\
\hline & EP & 0.002 & 0.046 & 0.006 & 0.041 & 0.968 \\
\hline & $\mathrm{P}$ & -0.236 & 0.176 & -0.172 & -1.34 & 0.186 \\
\hline & ME & -0.048 & 0.037 & -0.166 & -1.292 & 0.202 \\
\hline
\end{tabular}

The second hypothesis testing shows that environmental performance has no effect on CSR disclosure. This result is comparable to the study of Wijaya (2012) which states that the cause of the ineffectiveness of CSR disclosure is that CSR disclosures told by companies in which the activity is included in the PROPER indicator category are not widely disclosed in annual reports. The PROPER assessment should have become a community legitimacy for the company represented by the government program. In this research, there are still many companies that are not registered with the PROPER program and this indicates that the company is still not very aware of its environment. Furthermore, the third hypothesis testing shows that profitability has no effect on CSR disclosure. These results are in line with Giannarakis (2014), Dias et al. (2019), Fitriyani and Mutmainah (2012), Ramadhan (2019) and Aulia (2018). The rejection factor for this hypothesis is because companies with large profitability will not necessarily be motivated to carry out more social activities. This indicates that the company is still oriented more to the company's profit, management still generates more attention and is interested in disclosing information about its finances and considers it unnecessary to disclose things that can interfere with financial information such as information about its CSR.

William (1999) in Rashid (2015) argues that profitability does not affect the complete disclosure of CSR. Because the company is deemed not to need to fund in CSR initiatives and related to CSR it is more influenced by "public" pressure than "economic" pressure. Haifeng, et al. (2020) also revealed that an increase in the quality of CSR information disclosure itself increases the company's burden and hinders company performance. Finally, the four-hypothesis testing shows that media exposure has no effect on CSR disclosure. These results are in line with the research of Solikhah and Winarsih (2016) using a sample of 128 companies. There are still many sample companies that are inconsistent in providing disclosure of their CSR information through the company's official website platform in the 2017 - 2019 period. Submission of corporate social activities is able to provide sufficient and straightforward information to the general public who are still lying, when compared to understanding the company's annual report. Meanwhile, the company's annual report will be able to provide more detailed information related to social activities carried out during that period which is more specific to stakeholders in the company. The disclosure of CSR in the company's annual 
report is more detailed and specific because so far the sample in this study continues to disclose CSR even though the media is not a reference for disclosing it.

\section{Conclusion}

The results in this study indicate that the consumer proximity in this study has a significant effect on CSR disclosure. This is in line with the theory of legitimacy, in which this legitimacy theory encourages companies to ensure that companies in carrying out their operations have run according to the norms or rules that exist in society. Consumer proximity is likened to social visibility, where social visibility is obtained from consumers. Meanwhile, environmental performance variables, profitability and media exposure have no effect on CSR disclosure. The limitation of this study is that the results of this study cannot be generalized because the sample used in this study is relatively small with a total of 20 companies listed on the IDX 20172019. Many prospective sample companies do not publish sustainability reports because disclosures related to their social responsibility are already available in the annual report. Several susceptibility reports are incomplete and do not include indexes according to the applicable standards. This proves that the company still has minimal attention to CSR disclosures by company. It is recommended that the company be able to increase its social responsibility to the community and other stakeholders. This can be used as a positive reciprocal relationship. Suggestions for regulators to measure their performance in formulating policies and standards in regulating procedures and disclosure of CSR in Indonesia. For further research, it is necessary to add other variables that are more supportive of CSR disclosure because it is given that in accordance with the low determination coefficient value of $14.8 \%$.

\section{References}

Aulia, T. Z. (2018). Pengaruh Profitabilitas, Ukuran Perusahaan dan Kinerja Lingkungan Terhadap Corporate Social Responsibility Disclosure Berdasarkan Indikator Global Reporting Initiative (GRI) Pada Perusahaan Manufaktur yang terdaftar di Bursa Efek Indonesia. Jurnal Akuntansi dan Keuangan Univ Muhammadiyah Tangerang, 2(1), 1-7.

Branco, M. C. \& Rodrigues, L. L. (2008). Factors Influencing Social responsibility Disclosure by Portuguese, Companies Journal of Business Ethics, 83(4), 685-701.

Damanik, I. G. \& Yadnyana, I. K. (2017). Pengaruh Kinerja Lingkungan Pada Kinerja Keuangan Dengan Pengungkapan Corporate Social Responsibility Sebagai Variabel Intervening. E-Jurnal Akuntansi Universitas Udayana, 20(1), 645-673.

Dewi, I. A. \& Yasa, G. W. (2017). Pengaruh Ukuran Perusahaan, Profitabilitas, Tipe Industri dan Kinerja Lingkungan Terhadap Environmental Disclosure. E-Jurnal Akuntansi Universitas Udayana, 20(3), 2362-2391.

Dias, A., Rodrigues, L. L., Craig, R. \& Neves, M. E. (2019). Corporate Social Responsibility Disclosure in Small and Medium-Sized Entities and Large Companies. Social Responsibility Journal, 15(2), 137-154.

Fitriyani. \& Mutmainah, S. (2012). Keterkaitan Kinerja Lingkungan, Pengungkapan Corporate Social Responsibility CSR dan Kinerja Finansial. Diponegoro Journal of Accounting, 1-28. http://eprints.undip.ac.id/35522/1/jurnal.fitriyani.akt.regii.C2C607063.pdf

Freeman, R. E. E. \& McVea, J. (2001). A Stakeholder Approach to Strategic Management. SSRN Electronic Journal.

Giannarakis, G. (2014). The Determinants Influencing The Extent of CSR Disclosure. International Journal of Law and Management, 56(5), 393-416.

Haifeng, Z., Zhang, Z., Tan, A. \& Steklova, E. (2020). Quantity, Quality, and Performance of Corporate Social Responsibility Information Disclosure by Listed Enterprises in China: A Regional Perspective. International Journal of Environmental Research and Public Health, 17(7), 1-16.

Halmawati. \& Oktalia, D. (2015). Pengaruh Kinerja Lingkungan dan Profitabilitas Terhadap Corporate Social Responsibility Closure dalam Laporan Tahunan Perusahaan. Jurnal Kajian Manajemen Bisnis, 4(1993), 24.

Klerk, M., De, Villiers, C. \& Staden, C. (2015). The Influence of Corporate Social Responsibility Disclosure on Share Prices Evidence from the United Kingdom. Pacific Accounting Review, 27(2), 208-228. 
Lastiningsih, N., Aswar, K. \& Ermawati. (2020). Financial Performance in Indonesian Companies: The Role of Environmental Performance and Environmental Disclosure. Journal and Behavioral Studies, 12(2), 27-33.

Pakpahan, Y. \& Rajagukguk, L. (2018). Analisis Pengaruh Profitabilitas, Ukuran Perusahaan, Ukuran Dewan Komisaris, dan Media Exposure Terhadap Pengungkapan Tanggung Jawab Sosial. Jurnal Akuntansi, $18(2)$.

Partalidou, X., Zafeiriou, E., Giannarakis, G. \& Sariannidis, N. (2020). The Effect Of Corporate Social Responsibility Performance On Financial Performance: The Case Of Food Industry. Benchmarking, 27(10), 2701-2720.

Rashid, A. (2015). The Influence Of Stakeholder Power On Corporate Social Responsibility: Evidence From A Relationship-Based Economy. Social Responsibility Journal, 11(2), 270-289.

Ramadhan, A. (2019). Pengaruh Ukuran Perusahaan, Profitabilitas dan Kinerja Lingkungan Terhadap Corporate Social Responsibility Disclosure. Jurnal Ilmiah Akuntansi dan Keuangan, 8(1), 1-11.

Solikhah, B. \& Winarsih, A. M. (2016) pengaruh Liputan Media, kepekaan Industri, dan Struktur Tata Kelola Perusahaan terhadap Kualitas pengungkapan Lingkungan. Jurnal Akuntansi dan Keuangan Indonesia.

Syed, M. A. \& Butt, S. A. (2017). Financial And Non-Financial Determinants Of Corporate Social Responsibility: Empirical Evidence From Pakistan. Social Responsibility Journal, 13(4), 780-797.

Wang, J., Song, L. \& Yao, S. (2013). The Determinants Of Corporate Social Responsibility Disclosure: Evidence From China. Journal of Applied Business Research, 29(6), 1833-1847.

Wardhani, D. G. \& Sugiharto, T. (2013). Pengaruh Kinerja Keuangan, Ukuran Perusahaan, dam Kinerja Lingkungan Terhadap Intensitas Pengungkapan Pelaksanaan Tanggung Jawab Sosial Perusahaan Manufaktur yang Terdaftar di Bursa Efek Indonesia. Proceeding PESAT (Psikologi, Ekonomi, Sastra, Arsitektur \& Teknik Sipil, 5 Oktober 2013.

Wijaya, M. (2020). Faktor- Faktor yang Mempengaruhi Pengungkapan Tanggung Jawab Sosial: Studi Empiris Pada Perusahaan manufaktur yang terdaftar di BEI. Jurnal Akuntansi, 1(1).

Yingjun, L., Indra, A. \& Corinne, C. (2015). Corporate Social Responsibility Reporting Quality, Board Characteristics And Corporate Social Reputation: Evidence From China. In Pacific. Accounting Review, 27(1).

Yuliskayani, L. \& Damayanti, I. G. A E. (2018). Consumer Proximity, Media Exposure, Enviromental Sensitivity dan Profitability dalam Memengaruhi CSRD di Indonesia. E-Jurnal Akuntansi Universitas Udayana, 23(3), 1651-1681. 